\title{
Yalın Yönetim ve Örgütsel Güvene Yönelik Algının Örgütsel Özdeşleşmeye Etkisi: Özel Bir Hastanede Araştırma
}

\author{
Impact of Perception of Lean Management and Organizational Trust on \\ Organizational Identification: Research in a Private Hospital
}

\author{
Özlem ÖZER * \\ Okan $O ̈ Z K A N^{* *}$ \\ Sümeyye ÖZMEN ***
}

\begin{abstract}
$\ddot{O} Z$
Bu çalışmada yalın yönetim, örgütsel özdeşleşme ve örgütsel güven değişkenleri arasındaki ilişkilerin incelenmesi amaçlanmıştır. Çalışmanın evreni, İzmir ilinde bulunan özel bir hastanede görev yapan hemşireler ve diğer să̆llk çallş̧anlarından oluşmaktadır. Çalışmada örneklem seçilmemiş, tüm evrene erişilmeye çalışılmış ve böylece 121 kişi çallş̧maya katılım sağlamıştır. Çalı̧̧̧ada yapılan analizler sonucunda katılımcıların yalın yönetim, örgütsel özdeşleşme ve örgütsel güven algllarının yüksek düzeyde olduğu tespit edilmiştir. Çalışmada gerçekleştirilen korelasyon analizine göre, yalın yönetim ile örgütsel özdeşleşme; yalın yönetim ile örgütsel güven ve örgütsel özdeşleşme ile örgütsel güven arasında pozitif ve orta düzeyde ilişkiler tespit edilmiştir. Regresyon analizine göre katıllmcıların yalın yönetime ve örgütsel güvene yönelik algllarının örgütsel özdeşleşme üzerinde pozitif bir etkiye sahip olduğu belirlenmişstir. Bu doğrultuda katıllmcıların yalın yönetim ve örgütsel güven algılarının yükselmesi örgütsel özdeşleşme algılarını istatistiksel olarak artırmaktadır.
\end{abstract}

\author{
ANAHTAR KELIMELER \\ Yalın Yönetim, Örgütsel Özdeşleşme, Örgütsel Güven, Hastane
}

\begin{abstract}
The aim of this study is to examine the relationships between lean management, organizational identification, and organizational trust variables. The universe of the study consists of nurses and other healthcare professionals working in a private hospital in Izmir. The sample was not selected in the study, it was attempted to access the whole universe, and thus 121 people participated in the study. As a result of the analysis made in the study, it was determined that the participants' perceptions of lean management, organizational identification and organizational trust were at high levels. According to the correlation analysis performed in the study, positive and moderate relationships between lean management with organizational identification; lean management with organizational trust and organizational identification with organizational trust were determined. According to the regression analysis, it was determined that the perceptions of the participants towards lean management and organizational trust have a positive effect on organizational identification. In this direction, the increase in participants' perceptions of lean management and organizational trust increases their perceptions of organizational identification statistically.
\end{abstract}

\section{KEYWORDS}

Lean Management, Organizational Identification, Organizational Trust, Hospital

\begin{tabular}{|c|c|c|}
\hline \multicolumn{2}{|r|}{$\begin{array}{c}\text { Makale Geliş Tarihi / Submission Date } \\
05.02 .2021\end{array}$} & $\begin{array}{c}\text { Makale Kabul Tarihi / Date of Acceptance } \\
14.04 .2021\end{array}$ \\
\hline Attf & $\begin{array}{l}\text { Özer, Ö., Özkan, O. ve Özmen, S. }(2021 \\
\text { Etkisi: Özel Bir Hastanede Araştırma. } \\
100 .\end{array}$ & $\begin{array}{l}\text { gütsel Güvene Yönelik Algının Örgütsel Özdeşleşmeye } \\
\text { syal Bilimler Meslek Yüksekokulu Dergisi, } 24 \text { (1), 92- }\end{array}$ \\
\hline
\end{tabular}

\footnotetext{
* Doç. Dr., Sağlık Bilimleri Üniversitesi Gülhane Sağlık Bilimleri Fakültesi, ozlem.ozer@ sbu.edu.tr, ORCID: 0000-0002-7238-5371

** Dr. Öğr. Üyesi, Sağlık Bilimleri Üniversitesi Gülhane Sağlık Bilimleri Fakültesi, okan.ozkan@ sbu.edu.tr, ORCID: 0000-0001-9491-8696

*** Dr. Öğr. Üyesi, Burdur Mehmet Akif Ersoy Üniversitesi İktisadi ve İdari Bilimler Fakültesi, sozmen@ mehmetakif.edu.tr, ORCID: 0000-00023056-0872
} 


\section{GİRIŞ}

Günümüzde rekabetin yoğun olarak yaşandığı sağlık sektöründe, işletmelerin devamlılıklarını sağlayarak amaçlarına ulaşmaları ve sürdürülebilir rekabet üstünlüğünü elde etmeleri büyük önem taşımaktadır. Bu üstünlüğ̈ sağlamak için de sağlık kurum ve kuruluşlarında oldukça yeni bir yaklaşım sayılabilecek yalın yönetim kavramı ön plana çıkmaktadır. Yalın yönetim; sağlık kurum ve kuruluşlarının süreçlerinde israfın azaltılmasına, katma değer yaratmayan işlemlerin ortadan kaldırılmasına ve hizmet verilen süreçlerde uyumun sağlanarak verimliliğin artıılmasına yönelik bir yaklaşımı ifade etmektedir (Özkan ve diğ., 2015). Yalın uygulamaların hastanelerde süreçlerin hızlandırılması ve maliyetlerin azaltılması ve israfların ortadan kaldırılmasıyla beraber hasta güvenliğini de olumlu yönde etkilediği belirtilmektedir (Tınaz, 2019). Bu bağlamda sağlık kurumlarında yalın uygulamalara yönelik yapılacak çalışmalar; kullanılan malzemelerde israfın azaltılması, enerji tasarrufu yapılması, hasta ve çalışan tatmininin artırılması, işten ayrılma oranlarının düşürülmesi, yoğun bakım, ameliyathane ve servisler gibi bakım verilen birimlerde verimliliğin artırılması, hastane içerisinde görsel uyarıcı ve bilgilendirme işaretlerinin kullanılması, hizmet süreçlerinde iş akışlarının sadeleştirilmesi şeklinde ortaya çıkmaktadır (Aksoylu, 2014).

Sağlık kurumlarında yalın yönetim uygulamalarında çalışanların süreci benimseyerek katkıda bulunmaları, yalın yönetim uygulamalarının süreklilik sağlanmasında kritik bir öneme sahiptir. Yalın yönetim uygulamalarının başarıya ulaşmasında ise çalışanların kurumlarına karşı duydukları güven ve kurumla özdeşleşmeleri önemli faktörler olarak ortaya çıkmaktadır. Bu çalışmada yalın yönetim, örgütsel özdeşleşme ve örgütsel güven değişkenleri arasındaki ilişkileri incelemek amaçlanmıştır. Türkiye'de sağlık kurumlarında bu üç kavram arasındaki ilişkileri birlikte inceleyen çalışma bulunmamaktadır. Bu durum bu çalışmanın hazırlanmasında temel çıkış noktası olmaktadır.

\section{KAVRAMSAL ÇERÇEVE}

\subsection{Yalın Yönetim}

"Yalın" kavramı, israfi ortadan kaldırmak, katma değer yaratmayan işlemleri azaltmak ve katma değer yaratan işlemleri artırmak amacıyla gerekli olan faaliyet ve çözümleri ifade etmektedir (Wee ve Wu, 2009). Yalın yönetim, uzmanlar ve akademisyenler tarafindan tasarlanan Toyota üretim sisteminin prototipine dayanan ve 90'dan fazla otomobil fabrikası incelendikten ve Uluslararası Motorlu Taşıt Programında yer alan 17 ülkeyi kapsayacak şekilde dünya çapında karşılaştırmalı bir analiz yapıldıktan sonra 1990 yılında Massachusetts Teknoloji Enstitüsü'nde tertip edilen bir üretim yönetimi türü olan yalın üretimden türetilmiş bir kavramdır (Jing ve diğ., 2020). Yalın yönetimde, sisteme değer katmayan hiçbir uygulamaya devam edilmemekte, üretimin gerçekleşmesi için gerekli malzemelerin tüketiminin azaltılması amaçlanmakta, teknolojik açıdan gelişmiş cihazların ve yetişmiş personelin süreçte yer alması sağlanmakta ve doğru işin hatasız olarak yapılması hedeflenmektedir (Türkan, 2010). Yalın yönetim, hizmet verilen kişilerin talepleri doğrultusunda belirlenen kalite düzeyi ve standartları en kısa sürede ve tam olarak karşılayabilmek için örgütün süreçlerinin sadeleştirilmesini, gerekli olmayan ve kuruma katma değer sağlamayan faaliyetlerin sistemden çıartılmasını ve karar veren ile işi yapanın olabildiğince birbirine yaklaştırılmasını amaçlayan bir yönetim felsefesi olarak tanımlanmaktadır (Atsan, 1998). Başarıyla uygulandığında yalın üretim ve yönetim, örgütlerin süreçlerini iyileştirmelerine, atıkları azaltmalarına ve hatta ortadan kaldırmalarına yardımcı olabilmektedir (AlManei ve diğ., 2018). Yalın yönetim, hasta ve çalışan memnuniyetini artırmak, kaliteli hizmet sunmak, israf içeren unsurları ortadan kaldırmak, değer yaratan faaliyetlere odaklanmak, verimliliği artırmak için sağlık kurumları tarafından kullanılabilir bir yönetim tarzıdır (Tanyıldızı ve Demir, 2019). Birçok ülkedeki sağlık yöneticileri, hem personel hem de hastalar için verimliliği, klinik sonuçları, memnuniyeti ve güvenliği artırmak ve sonuç olarak finansal performansı ve sürdürülebilirliği artırmak için yalın yönetim araçlarını kullanmaktadır (Çilhoroz ve Arslan, 2018).

\section{2. Örgütsel Özdeşleşme}

Örgütsel özdeşleşme, örgütsel davranış alanında temel bir kavram haline gelmiş ve yönetim araştırmalarında dikkat çeken bir konu olmuştur. Bunun nedeni örgütsel özdeşleşmenin, çalışanın ve örgütün arasında var olan temel bağlantıyı veya bağı yansıtan ve bu nedenle potansiyel olarak işyerlerindeki birçok önemli tutum ve davranışı açıklayıp tahmin edebilen kilit bir psikolojik durum olarak görülmesidir (Edwards, 2005). Örgütsel özdeşleşme çalışmaları, sosyal kimlik kuramından türetilmiştir. Tajfel (1978) sosyal kimliği, "bireyin benlik kavramının bir sosyal gruba (veya gruplara) üyeliğine ilişkin bilgisiyle birlikte bu üyeliğe ilişkin değer veya duygusal önemden kaynaklanan parçası” olarak tanımlamaktadır. Sosyal kimlik kuramına göre birey, kendisini kısmen öne çıkan grup üyelikleri açısından tanımlamaktadır. Özdeşleşme, bir grupla bir 
olma veya bir gruba ait olma algısıdır ve bu grubun başarıları ve başarısızlıklarının doğrudan veya temsili deneyimini içermektedir. Örgütsel özdeşleşme, bir sosyal yığınla birlik olma veya bir sosyal kümeye ait olma algısı olarak tanımlanmaktadır (Ashforth ve Mael, 1989). Bir başka tanıma göre örgütsel özdeşleşme; çalışan kişinin, örgütü tanımladığı kimlik çerçevesinde kendisini de benzer özelliklerle tanımlama derecesidir (Dutton ve diğ., 1994). Bir diğer değişle bireyin başarısını ve başarısızlığını örgütün başarısı ve başarısızlığı ile ilişkilendirdiği bilişsel bir durumdur. Dolayısıyla örgütsel özdeşleşme, bireyleri olumlu örgütsel tutum ve davranışlar sergilemeye motive eden bir kavramdır (Pattnaik ve Tripathy, 2020). Örgütsel özdeşleşme; karar verme süreçleri, iş doyumu/tatmini, örgütsel hedeflere ulaşma, rol çatışması, çalışanlar arası etkileşim, işten ayrılma niyeti, iş verimliliği ve iş performansı gibi örgütsel olguları ve çalışanların örgütsel davranışlarını etkilemektedir (Envergil, 2018).

\section{3. Örgütsel Güven}

Güven, "bir tarafin, diğer tarafı izleme veya kontrol etme becerisinden bağımsız olarak, diğer tarafin, güvenen için önemli olan belirli bir eylemi gerçekleştireceği beklentisine dayanarak, başka bir tarafin eylemlerine karşı savunmasız olmaya istekli olmasıdır" (Mayer ve diğ., 1995). Blomqvist ve Stähle (2000)'ye göre ise güven, "bir etken öznenin karşı tarafın yeterlilik, iyi niyet ve davranışı konusundaki beklentisi" olarak tanımlanmaktadır. Örgütsel güven, bir işverene duyulan güven ve destek duygusunu ifade etmektedir ve bir işverenin açık sözlü olacağı ve taahhütleri yerine getireceği inancı şeklinde tanımlanmaktadır (Gilbert ve Tang, 1998).

Güven faktörünün örgütlerde kontrol mekanizmalarının ve örgüt içi yapıların oluşturduğu maliyetlerin azaltılmasında, bilgi paylaşımının artırılmasında, örgüt içinde ayrışmaların engellenmesinde, karar verme süreçlerindeki belirsizliklerin ortadan kaldırılmasında yardımcı olan önemli bir faktör olduğu ifade edilmektedir (Tüzün, 2006). Ayrıca güvenin; çalışanların işbirliği davranışı, örgütsel vatandaşlık davranışı, örgütsel bağl1lık ve çalışan sadakati gibi olumlu tutum ve davranışlarının etkili bir göstergesi olabileceği de belirtilmektedir (Yu ve diğ., 2018). Örgüt içinde güveni temel alan ilişkilerin oluşturulması, çalışanların yöneticilerine ve bir bütün olarak örgüte güven duyması, kendini örgüt içinde tanımlayabilmesi sayesinde yaptığı işlerden tatmin olması, örgütten ayrılmayı düşünmemesi ve kurum bağl1lı̆̆ının artması mümkün olabilmektedir (Demircan ve Ceylan, 2003). Bu nedenle çalışanın örgütüne olan güvenini artırmak, tüm işverenlerin ideal hedefi olarak ortaya çıkmaktadır. Bununla birlikte örgütsel güvenin nasıl sağlanacağı konusu ise örgütlerin karşı karşıya kaldığı bir zorluk olarak kendini göstermektedir (Yu ve diğ., 2018). Ancak çalışanların birbirleri arasında ve yönetime karşı güven duymasının, kurumda görev alan her çalışan açısından bir gereklilik olarak görülmesi gerekmektedir (Asunakutlu, 2002).

\section{YÖNTEM}

\subsection{Amaç ve Hipotez}

Bu çalışmanın amacı yalın yönetim, örgütsel özdeşleşme ve örgütsel güven değişkenleri arasındaki ilişkileri incelemektir. Çalışmanın amacı doğrultusunda oluşturulan araştırma hipotezleri şu şekildedir:

Hipotez 1: Katılımcıların yalın yönetime yönelik algıları örgütsel özdeşleşme üzerinde pozitif bir etkiye sahiptir.

Hipotez 2: Katılımcıların örgütsel güvene yönelik algıları örgütsel özdeşleşme üzerinde pozitif bir etkiye sahiptir.

\subsection{Evren ve Örneklem}

Çalışmanın evreni, İzmir ilinde yer alan özel bir hastanede görev yapmakta olan hemşirelerden ve diğer sağlık çalışanlarından oluşmaktadır. Hastanede 56 hemşire ve 130 diğer sağlık çalışanı (sağlık teknisyeni, sağlık teknikeri, biyolog vb. gibi) görev yapmaktadır. Çalışmada örneklem seçilmemiş ve araştırmada kullanılan veri toplama aracı, araştırmada yer almak isteyen tüm kişilere dağıtılmıştır. Veri toplama süreci 11 Ocak-25 Ocak 2021 tarihleri arasında gerçekleştirilmiştir ve çalışmada 121 kullanılabilir anket elde edilmiştir.

Çalışmanın gerçekleştirilmesi için Burdur Mehmet Akif Ersoy Üniversitesi Etik Kurulu'ndan (Karar No: GO2021/20) gerekli izinler alınmıştır. Katılımcılara toplanan verilerin yalnızca bilimsel amaçla kullanılacağı bildirilmiştir.

\subsection{Veri Toplama Aracı}

Çalışmada katılımcıların yalın yönetime yönelik algılarını değerlendirmek için Derin (2008) tarafından geliştirilen, Denizli (2020) tarafından geçerlik ve güvenirliği yapılan "Yalın Yönetim Ölçeğì" kullanılmıştır. Ölçek 24 maddeden oluşmaktadır ve 5'li Likert tipinde (1-Kesinlikle Katılmıyorum, 5-Kesinlikle Katılıyorum)

Selçuk Üniversitesi Sosyal Bilimler Meslek Yüksekokulu Dergisi, Yıl: 2021 Cilt: 24 Sayı:1 
değerlendirilmektedir. Ölçeğe ilişkin örnek sorular; "Kurumunuz sizlere değer vermektedir”, "Kurumunuzda takım ruhu hâkimdir" şeklindedir.

Katılımcıların örgütsel özdeşleşme düzeyini ölçmek için, Mael ve Ashforth (1992) tarafından geliştirilen, Tüzün (2006) tarafından geçerlik ve güvenirliği yapılan, 6 maddeden ve tek faktörden oluşan "Örgütsel Özdeşleşme Ölçeğì" kullanılmıştır. Ölçek, 5'li Likert tipinde (1-Kesinlikle Katılmıyorum, 5-Kesinlikle Katılıyorum) değerlendirilmektedir. Ölçeğe ilişkin örnek sorular; "Diğer insanların çalıştığım işletme hakkındaki düşünceleri beni çok ilgilendirir", "Çalıştığım işletmenin başarısı benim başarımdır" şeklindedir.

Katılımcıların örgütsel güven düzeyleri ölçmek için ise Tyler ve Bies (1990) tarafından geliştirilen ve Polat (2009) tarafından Türkçe'ye uyarlanan 4 maddeden ve tek boyuttan oluşan "Örgütsel Güven Ölçeği" kullanılmıştır. Ölçek, 5'li Likert tipinde (1-Kesinlikle Katılmıyorum, 5- Kesinlikle Katılıyorum) değerlendirilmektedir. Ölçeğe ilişkin örnek sorular; "Yöneticilerime güvenebilirim", "Çalıştı̆̆ım iş yerinde yönetime büyük güven duyuyorum" şeklindedir.

Çalışmada yalın yönetim ölçeğinin güvenirlik değeri 0,978 ; örgütsel özdeşleşme ölçeğinin güvenirlik değeri 0,929 ve örgütsel güven ölçeğinin güvenirlik değeri 0,906 olarak bulunmuştur. Literatürde Cronbach Alpha değeri 0,79'un üzerinde olduğunda, ölçeğin yüksek güvenirliğe sahip olduğu ifade edilmektedir (Alpar, 2012). Dolayısıyla bu çalışmada kullanılan ölçeklerin yüksek oranda güvenilir olduğu sonucuna varılmıştır.

\subsection{Verilerin Analizi}

Verilerin analizinde tanımlayıcı analizler, güvenirlik analizi, korelasyon analizi ve regresyon analizi kullanılmıştır.

\section{BULGULAR}

Tablo 1'de çalışmaya katılanlara ilişkin tanımlayıcı bulgular yer almaktadır. Tablo incelendiğinde katılımcıların \%52,1'inin 31 yaş ve üzerinde olduğu, \%62,8'inin kadın olduğu ve \%42,2'sinin lise düzeyinde eğitime sahip olduğu görülmektedir. Katılımcıların \%28,1'i hemşirelerden ve \%71,9'u diğer sağlık çalışanlarından oluşmaktadır. Katılımcıların \%51,2'si sağlık sektöründe toplam çalışma süresinin 5 yıl ve daha az olduğunu belirtirken, \%61,2'si mevcut hastanede çalışma süresinin 3 yıl ve daha fazla olduğunu belirtmiştir.

Tablo 1. Araştırmaya Katılanların Tanımlayıcı Özellikleri

\begin{tabular}{|c|c|c|}
\hline Değişkenler & Sayı & Yüzde \\
\hline \multicolumn{3}{|l|}{ Yas } \\
\hline$-\quad \leq 30$ & 58 & 47,9 \\
\hline$-\quad 31 \geq$ & 63 & 52,1 \\
\hline \multicolumn{3}{|l|}{ Cinsiyet } \\
\hline - Kadın & 76 & 62,8 \\
\hline - Erkek & 45 & 37,2 \\
\hline \multicolumn{3}{|l|}{ Eğitim } \\
\hline - Lise & 51 & 42,2 \\
\hline - Önlisans / İki Yıllık Yüksekokul & 34 & 28,1 \\
\hline - Dört Yılllık Yüksekokul / Fakülte & 31 & 25,6 \\
\hline - Yüksek lisans ya da doktora & 5 & 4,1 \\
\hline \multicolumn{3}{|l|}{ Hastanedeki Görev } \\
\hline - Hemşire & 34 & 28,1 \\
\hline - Diğer Sağlık Çalışanları & 87 & 71,9 \\
\hline \multicolumn{3}{|l|}{ Sağlık Sektöründe Toplam Çalıșma Süresi (Yıl) } \\
\hline$-\quad \leq 5$ & 62 & 51,2 \\
\hline$-6 \geq$ & 59 & 48,8 \\
\hline \multicolumn{3}{|l|}{ Mevcut Çalışılan Hastanede Görev Süresi (Yıl) } \\
\hline$-\quad \leq 2$ & 47 & 38,8 \\
\hline$-\quad 3 \geq$ & 74 & 61,2 \\
\hline
\end{tabular}

Tablo 2'de yer alan araştırma değişkenlerine ilişkin temel istatistiklere bakıldığında, katılımcıların yalın

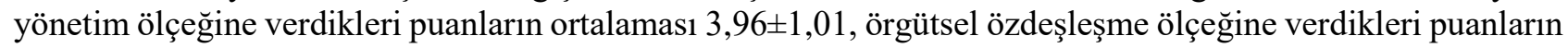

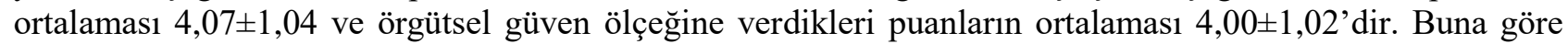
katılımcıların yalın yönetim, örgütsel özdeşleşme ve örgütsel güven algılarının yüksek bir düzeyde olduğu söylenebilir. Yapılan korelasyon analizi sonucuna göre, yalın yönetim ile örgütsel özdeşleşme arasında pozitif ve orta düzeyde $(\mathrm{r}=, 516 ; \mathrm{p}<0,01)$ ve yalın yönetim ile örgütsel güven arasında da pozitif ve orta düzeyde $(\mathrm{r}=$ 
,583; $\mathrm{p}<0,01$ ) ilişkiler bulunmuştur. Ayrıca örgütsel özdeşleşme ile örgütsel güven arasında da pozitif ve orta düzeyde bir ilişki tespit edilmiştir $(r=, 623 ; p<0,01)$.

Tablo 2. Araştırma Değiş̧kenlerine İlişsin Tanımlayıcı İstatistikler ve Korelasyon Değerleri

\begin{tabular}{|l|c|c|c|c|c|}
\hline Değişkenler & Ort. & S.S. & Yalın Yönetim & $\begin{array}{c}\text { Örgütsel } \\
\text { Özdeşleşme }\end{array}$ & Örgütsel Güven \\
\hline Yalın Yönetim & 3,96 & 1,01 & 1 & & \\
\hline Örgütsel Özdeşleşme & 4,07 & 1,04 &, $516^{* *}$ & 1 & \\
\hline Örgütsel Güven & 4,00 & 1,02 &, $583^{* *}$ &, $623^{* *}$ & 1 \\
\hline ***p $<0.01$ S.S.: Standart Sapma
\end{tabular}

Araştırmada yer alan hipotezlerin test edilmesi amaciyla regresyon analizi uygulanmış ve iki farklı regresyon modeli oluşturulmuştur (Tablo 3). Yalın yönetim algısının örgütsel özdeşleşme üzerine etkisine ilişkin yürütülen regresyon analizi sonucuna göre; yalın yönetim algısının örgütsel özdeşleşme üzerindeki toplam varyansın \%26,6'sını açıkladığı görülmektedir. Analiz sonuçlarına göre katılımcıların yalın yönetim algılarının yükselmesi örgütsel özdeşleşme algılarını istatistiksel olarak artırmaktadır $(\beta=0,516, t=6,573$; $\mathrm{p}<0,001)$. Bu sonuçlar " H1: Katılımcıların yalın yönetime yönelik algıları örgütsel özdeşleşme üzerinde pozitif bir etkiye sahiptir" hipotezini doğrulamaktadır.

Oluşturulan ikinci regresyon analizi sonuçları incelendiğinde katılımcıların örgütsel güven algılarının örgütsel özdeşleşme üzerindeki toplam varyansın \%38,9'unu açıkladığ1 görülmektedir. Analiz sonuçları, örgütsel güven algısının yükselmesinin örgütsel özdeşleşme algısını istatistiksel olarak artırdığını göstermektedir $(\beta=0,623, \mathrm{t}=8.698, \mathrm{p}<0.001)$. Bu sonuçlar "H2: Katılımclların örgütsel güvene yönelik algıları örgütsel özdeşleşme üzerinde pozitif bir etkiye sahiptir” hipotezini doğrulamaktadır.

Tablo 3. Regresyon Analizi Sonuçları

\begin{tabular}{|c|c|c|c|c|c|c|}
\hline 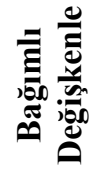 & Bağımsız Değişkenler & $B$ & $\begin{array}{c}\text { Std. } \\
\text { Hata }\end{array}$ & $\boldsymbol{\beta}$ & $t$ & $p$ \\
\hline \multirow{2}{*}{ 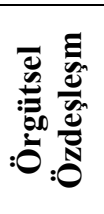 } & $\begin{array}{l}\text { (Sabit) } \\
\text { Yalın Yönetim }\end{array}$ & $\begin{array}{r}1,962 \\
, 532 \\
\end{array}$ & $\begin{array}{l}, 331 \\
, 081 \\
\end{array}$ &, 516 & $\begin{array}{l}5,931 \\
6,573 \\
\end{array}$ & $\begin{array}{l}<0,001 \\
<0,001\end{array}$ \\
\hline & $R=0,516$ & $R^{2}=, 266$ & $F=43,200$ & $p<0,00$ & & \\
\hline \multirow{2}{*}{ 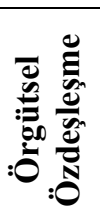 } & $\begin{array}{l}\text { (Sabit) } \\
\text { Örgütsel Güven }\end{array}$ & \begin{tabular}{|r|}
1,515 \\
, 638 \\
\end{tabular} & \begin{tabular}{l|l}
, 303 \\
\\
\end{tabular} & ,623 & $\begin{array}{l}5,001 \\
8,698 \\
\end{array}$ & $\begin{array}{l}<0,001 \\
<0,001 \\
\end{array}$ \\
\hline & $R=, 623$ & $R^{2}=, 389$ & $F=75,648$ & $p<0,001$ & & \\
\hline
\end{tabular}

\section{TARTIŞMA}

Yalın yönetim uygulamalarının başarılı olması noktasında çalışan katılımı ve desteği büyük önem taşımaktadır. Çalışanların örgüte duydukları özdeşleşme algısının yüksek olması ise yalın yönetimin başarılı olmasında kilit bir öneme sahiptir. Bu çalışmada yalın yönetim, örgütsel özdeşleşme ve örgütsel güven değişkenleri arasındaki ilişkileri incelemek amaçlanmıştır. Literatür incelendiğinde sağlık çalışanları üzerinde yalın yönetim, örgütsel özdeşleşme ve örgütsel güven değişkenlerini birlikte ele alan bir çalışmanın yapılmamış olması bu çalışmanın özgün değerini oluşturmaktadır. Bu nedenle de bu çalışmanın sonuçlarının literatürdeki boşluğu doldurmak adına katkı sağlayacağı düşünülmektedir.

Çalışmada yapılan analizler sonucunda katılımcıların yalın yönetim algılarının yüksek düzeyde olduğu belirlenmiştir. Yetgin ve Sur (2000) tarafından yapılan çalışmada da sağlık çalışanlarının yalın yönetim uygulamalarına ilişkin algı düzeylerinin yüksek olduğu tespit edilmiştir. Çınar ve diğ. (2013) ise yaptıkları çalışmalarında yalın hizmet yönetimi faktörlerinin orta düzeylerde olduğunu belirlemiştir. Yalın yönetim, sağlık sektöründe uygulamaları yaygınlaşan ve sağlık kurumlarına rekabet avantajı sağlayan bir felsefe olarak öne çıkmaktadır (Tanyıldızı ve Demir, 2019). Yalın yönetim uygulamalarının yeterli düzeyde kaynak ayıran, 
yalın yönetim konusunda hem üst yönetimin hem de çalışanların desteğinin ve farkındalığının olduğu, değişime ve yeniliklere açık örgütlerde daha kolay gerçekleştirilebileceği vurgulanmaktadır (Özkan ve Orhaner, 2018). Bu nedenle de sağl1k kurumlarında yalın yönetim kültürünün oluşturulması ve bu kültürün çalışanlar tarafından benimsenmesi oldukça önemlidir.

Çalışmada katılımcıların örgütsel özdeşleşme ve örgütsel güven algılarının da yüksek seviyede olduğu tespit edilmiştir. Tokgöz ve Aytemiz Seymen (2013)'in çalışmalarında da aynı şekilde katılımcıların örgütsel özdeşleşme algılarının yüksek olduğu belirlenmiştir. Envergil (2018), Öktem ve diğ. (2016) ve Çankaya (2020)'ın çalışmalarında ise katılımcıların örgütsel güven ve örgütsel özdeşleşme puan ortalamalarının orta seviyede olduğu tespit edilmiştir. Kaynakların adaletli dağıtımı, net ve herkes için geçerli olan standartlar ve eşitlikçi uygulamalar sağlık personelinde örgütsel özdeşleşme ve örgütsel güven düzeyini artırmaktadır (Chen ve diğ., 2015). Dolayısıyla da bu sonucun, adalet ve eşitliğe dair duyulan hassasiyetten kaynaklanabileceği düşünülmektedir.

Yapılan bu çalışmada yalın yönetim ile örgütsel özdeşleşme ve yalın yönetim ile örgütsel güven arasında pozitif ve orta düzeyde ilişkiler bulunmuştur. Çalışmada yapılan regresyon analizi sonucuna göre, yalın yönetim algısının örgütsel özdeşleşme üzerindeki toplam varyansın \%26.6'sını açıkladığı tespit edilmiştir. Analiz sonuçlarına göre katılımcıların yalın yönetime ilişkin algılarının yükselmesi örgütsel özdeşleşme algılarını istatistiksel olarak artırmaktadır. Literatürde yalın yönetime yönelik yapılan çalışmalar incelendiğinde; Bayar (2020) yalın yönetim uygulamalarının çalışanların görev performansını istatistiksel olarak anlamlı düzeyde etkilediğini saptamıştır. Denizli (2020) çalışmasında yalın yönetim uygulamalarının insan kaynakları yönetimi uygulamaları üzerinde pozitif ve anlamlı etkiye sahip olduğunu tespit etmiştir. Akgemci ve diğ. (2020) ise çalışmalarında iş doyumu, motivasyon ve yalın yönetim algısı arasında pozitif yönde anlamlı bir ilişki olduğunu belirlemiştir. Bıkmaz (2019) hemşirelerde gerçekleştirdiği çalışmasında yalın yönetim, örgütsel stres ve sosyal destek düzeyi arasında pozitif yönde zayıf bir ilişki tespit etmiştir. Son olarak Çınar ve diğ. (2013) de çalışmalarında yalın hizmet yönetimi ile örgütsel bağlılık arasında doğrusal yönde çeşitli düzeylerde ilişkiler bulmuştur.

Çalışmada örgütsel özdeşleşme ile örgütsel güven arasında pozitif ve orta düzeyde bir ilişki tespit edilmiştir. Yapılan regresyon analizi sonuçlarına göre örgütsel güven algısının örgütsel özdeşleşme üzerindeki toplam varyansın \%38.9'unu açıkladığı belirlenmiştir. Buna göre örgütsel güven algısının yükselmesi örgütsel özdeşleşme algısını istatistiksel olarak artırmaktadır. Bu sonuçlar literatürde yapılan diğer çalışmaların sonuçları ile de benzerlik göstermektedir. Buna göre; Tokgöz ve Aytemiz Seymen (2013), Tüzün (2006), Polat (2009) ve Tekingündüz ve diğ. (2020)'nin gerçekleştirmiş oldukları çalışmalarında örgütsel güven ve örgütsel özdeşleşme arasında anlamlı ve pozitif bir ilişki tespit edilmiştir. Çankaya (2020)'nın sağlık sektöründe gerçekleştirdiği çalışmasında ise örgütsel güven ile örgütsel özdeşleşme arasında zayıf düzeyde ve pozitif yönde anlamlı bir ilişki tespit edilmiştir. Envergil (2018)'in sağlık çalışanları üzerinde gerçekleştirdiği çalışmasında da örgütsel güven düzeyi ile örgütsel özdeşleşme arasında olumlu yönde ancak zayıf bir ilişki olduğu ve çalışanların örgütsel güven düzeyinin örgütsel özdeşleşme algılarındaki toplam varyansın \%13.3'ünü açıkladığı tespit edilmiştir. Demirtaş ve diğg. (2018)'nin çalışmalarında ise algılanan örgütsel güven ile örgütsel özdeşleşme arasında pozitif yönlü anlamlı bir ilişki olduğu ve örgütsel özdeşleşmedeki değişimin \%25.4'ünün algılanan örgütsel güven tarafından açıklandığını belirlenmiştir. Öktem ve diğg. (2016) ve Polat (2006)'ın çalışmalarında da örgütsel güvenin örgütsel özdeşleşmeyi etkilediği belirlenmiştir.

Örgütsel özdeşleşme ve örgütsel güven kavramları, kurum aidiyetinin oluşması, iş performansının ve verimliliğin artırılması noktasında oldukça etkili faktörlerdir. Çalışanlar, görev aldıkları kurum ile güçlü bir özdeşleşme yaşadıklarında, çalışmaya devam etmek istemekte ve kurumun çıkarlarına uygun karar alma ve hareket etme ihtimalleri artmaktadır (Scott, 2020). Bu nedenle örgütsel özdeşleşme, sağlık kurumlarında çalışan devamlılığının sağlanması için oldukça önemlidir. Nitekim Polat (2009) tarafından yapılan çalışmada örgütsel özdeşleşme düzeyindeki artışın işten ayrılma niyeti üzerinde olumsuz etkisi olduğu tespit edilmiştir. Chen ve diğ. (2015) tarafından yapılan çalışmada da örgütsel güven ve örgütsel özdeşleşmenin hemşirelerin isteyerek işlerinde kalmalarına ve kendilerini hastaneye adamalarına sebep olduğu bulunmuştur. Uğurlu ve diğ. (2015) ise çalışanların örgüte güven duymasının kurumun amaçlarını ve hedeflerini yerine getirmesi konusunda çaba harcamalarına, işine bağlı olmalarına ve yüksek morale sahip olmalarına yardımcı olduğunu belirtmektedir. Gün ve Turabik (2017) de örgütsel özdeşleşme düzeylerinin yükseltilmesinin çalışanların performansı üzerinde olumlu etkileri olacağından ve çalışanların örgütün değerleriyle bütünleşmesine imkân sağlayacağından bahsetmektedir.

Sağlık kurumlarındaki yöneticilerin, karar alma süreçlerinde çalışan katılımı ve desteğini ön planda tutarak değer yaratan faaliyetlere odaklanması, israfı ve maliyetleri azaltma yolunda da müşteri istek ve ihtiyaçlarına yönelik yalın yönetim yaklaşımını esas alarak hareket etmesi oldukça önemlidir. $\mathrm{Bu}$ nedenle de sağlık 
kurumları yöneticilerinin yalın yönetim uygulamalarına gereken önemi vermesi, kök neden analizleri yapılarak ve problem çözme tekniklerinden yararlanarak israf noktalarının ortadan kaldırılması, değer yaratmayan faaliyetlerin azaltılması, çalışanların ve yöneticilerin bu konuda eğitilmesi ve örgütlerinde yalın yönetim kültürünün yerleştirilmesi önerilmektedir. Sağlık kurumlarının bu süreçte başarılı olmaları noktasında ise çalışanların örgütlerine güven duyarak yüksek düzeyde özdeşleşme göstermesi büyük bir rol oynamaktadır. $\mathrm{Bu}$ doğrultuda da personelin örgütsel güven ve örgütsel özdeşleşme algılarının olumlu yönde olması için kurumlarda gerekli iyileştirilmelerin ve çalışmaların yapılması önerilmektedir.

Bu çalışmanın sonuçlarının tüm hastane çalışanlarına genellenmesi konusunda sınırlılıkları bulunmaktadır. Çalışma, bir ilde ve özel bir hastanede çalışanlar üzerinde gerçekleştirilmiştir. Dolayısıyla gelecekte farklı ve daha geniş örneklemler üzerinde araştırmaların yapılması ve yalın yönetim ile farklı değişkenler (örgütsel vatandaşlık, örgütsel adalet, örgütsel stres, örgüt kültürü vb. gibi) arasındaki ilişkilerin incelenmesi önerilmektedir. 


\section{KAYNAKÇA}

Akgemci, T., Canbolat, M.A. ve Kalfaoğlu, S. (2020). "Yalın Yönetim Anlayışıyla Yönetilen Mavi Yakalıların Motivasyon, İş Tatmini ve Yetenek Yönetimi Algılarının Belirlenmesine Yönelik İmalat Sektöründe Bir Araştırma”, Abant İzzet Baysal Üniversitesi Sosyal Bilimler Enstitüsü Dergisi, 20(1), 169-187.

Aksoylu, S. (2014). "Hastane İşletmelerinde Değer Akış Maliyetlemesi”, Niğde Üniversitesi İktisadi ve İdari Bilimler Fakültesi Dergisi, 7(1), 260-272.

AlManei, M., Salonitis, K. and Tsinopoulos, C. (2018). “A Conceptual Lean Implementation Framework Based on Change Management Theory", Procedia CIRP, 72, 1160-1165.

Alpar, R. (2012). Uygulamalı İstatistik ve Geçerlik-Güvenirlik, Detay Yayıncılık, Ankara.

Ashforth, B.E. and Mael, F. (1989). "Social Identity Theory and the Organization", Academy of Management Review, 14(1), 20-39.

Asunakutlu, T. (2002). “Örgütsel Güvenin Oluşturulmasına İlişkin Unsurlar ve Bir Değerlendirme”, Muğla Üniversitesi Sosyal Bilimler Enstitüsü Dergisi, 9, 1-13.

Atsan, N. (1998). “Yalın Yönetim Yaklaşımı ve Türkiye'deki Uygulamalara İlişkin Bir Alan Araştırması”, Yüksek Lisans Tezi, Akdeniz Üniversitesi, Sosyal Bilimler Enstitüsü, Antalya.

Bayar, M. (2020). "Yalın Yönetim Anlayışının, Çalışanların Görev Performansına Etkilerine Yönelik Bir Araştırma", İşletme Araştırmaları Dergisi, 12(2), 1984-2001.

Bıkmaz, Z. (2019). "The Relationship Between Percevied Lean Management and Organizational Stress Levels Among Nurses”, 2. Uluslararası İnsan Çalışmaları Kongresi, 23-24 Kasım, Ankara.

Blomqvist, K. and Ståhle, P. (2000). "Building Organizational Trust”, 16th Annual IMP Conference, Bath, UK (pp. 7-9).

Chen, SY., Wu, W.C., Chang, C.S., Lin, C.T., Kung, J.Y., Weng, H.C., Lin, Y.T. and Lee, S.I. (2015). "Organizational Justice, Trust, and Identification and Their Effects on Organizational Commitment in Hospital Nursing Staff”, BMC Health Services Research, 15, 363.

Çankaya, M. (2020). "Örgütsel Güvenin Örgütsel Özdeşleşme Üzerindeki Etkisi: Sağlık Sektöründe Bir Uygulama”, Akademik Sosyal Araştırmalar Dergisi, 8(107), 185-204.

Çınar, F., Ekinci, G. ve Uzuncaköse, M. (2013). "Kamu Sağlık Sektöründe Çalışan Personelin Örgütsel Bağlılığının Yalın Hizmet Yönetimine Etkisi”, 7. Ulusal Sağlık ve Hastane İdaresi Kongresi Bildiri Kitabı, 27-29 Eylül, Konya.

Çilhoroz, Y. ve Arslan, İ. (2018). "Yalın Yönetim Yaklaşımı ve Sağlık Hizmetlerinde Uygulamaları", Süleyman Demirel Üniversitesi Sosyal Bilimler Enstitüsü Dergisi, 3(32), 156-185.

Demircan, N. ve Ceylan, A. (2003). “Örgütsel Güven Kavramı: Nedenleri ve Sonuçları”, Yönetim ve Ekonomi: Celal Bayar Üniversitesi İktisadi ve İdari Bilimler Fakültesi Dergisi, 10(2), 139-150.

Demirtaş, Ö., Biçkes, D.M. ve Yılmaz, C. (2018). “Örgütsel Kimlik ve Güven Algılamalarının Örgütsel Özdeşleşme Üzerindeki Etkisi”, International Journal of Disciplines Economics \& Administrative Sciences Studies, 4(8), 274285.

Denizli, Ö. (2020). “İşletmelerde Yalın Yönetim Uygulamalarının İnsan Kaynakları Yönetimi Üzerindeki Etkisi”, Yüksek Lisans Tezi, Bahçeşehir Üniversitesi, Sosyal Bilimler Enstitüsü, İstanbul.

Derin, N. (2008). “Çalışanların Algılamalarına göre, Yalın Yönetimin İç İmaja Etkisi: Türkiye'deki Özel Hastanelerde Bir Araştırma”, Doktora Tezi, İnönü Üniversitesi, Sosyal Bilimler Enstitüsü, Malatya.

Dutton, J.E., Dukerich, J.M. and Harquail, C.V. (1994). "Organizational Images and Member Identification", Administrative Science Quarterly, 239-263.

Edwards, M.R. (2005). “Organizational Identification: A Conceptual and Operational Review”, International Journal of Management Reviews, 7(4), 207-230.

Envergil, D. (2018). "Sağlık Çalışanlarının Psikolojik Sözleşme Algılarının Örgütsel Güven, Örgütsel Özdeşleşme ve Örgütsel Vatandaşlık Davranışı Üzerindeki Etkisi”, Yüksek Lisans Tezi, Hacettepe Üniversitesi, Sosyal Bilimler Enstitüsü, Ankara.

Gilbert, J.A. and Tang, T.L.P. (1998). “An Examination of Organizational Trust Antecedents”, Public Personnel Management, 27(3), 321-338.

Gün, F. ve Turabik, T. (2017). “Öğretim Elemanlarının Algılarına göre Psikolojik Güçlendirme ile Örgütsel Özdeşleşme Arasındaki İlişskinin İncelenmesi”, Mersin Üniversitesi Eğitim Fakültesi Dergisi, 13(3), 886-905.

Jing, S., Li, R., Niu, Z. and Yan, J. (2020). “The Application of Dynamic Game Theory to Participant's Interaction Mechanisms in Lean Management”, Computers \& Industrial Engineering, 139, 106196.

Mael, F. and Ashforth, B.E. (1992). "Alumni and Their Alma Mater: A Partial Test of the Reformulated Model of Organizational Identification", Journal of Organizational Behavior, 13(2), 103-123.

Mayer, R.C., Davis, J.H. and Schoorman, F.D. (1995). “An Integrative Model of Organizational Trust”, Academy of Management Review, 20(3), 709-734.

Öktem, Ş., Kızıltan, B. and Öztoprak, M. (2016). "The Effects of Organizational Climate and Organizational Trust on Organizational Identification, Job Satisfaction and Intention of Turnover: An Application in Hotel Management”, Journal of Business Research Turk, 8(4), 162-186.

Özkan, O. ve Orhaner, E. (2018). “Özel Hastane Yöneticilerinin Yalın Yönetim Yaklaşımına İlişkin Görüşleri; Ankara İli Örneği”, Türkiye Sağlık Bilimleri ve Araştırmaları Dergisi, 1(1), 1-12. 
Özkan, O., Bayın, G. ve Yeşilaydın, G. (2015). “Sağlık Sektöründe Yalın Tedarik Zinciri Yönetimi”, AJIT-e: Bilişim Teknolojileri Online Dergisi, 6(18), 71-94.

Pattnaik, S. and Tripathy, S. K. (2020). "Organizational Identification (OID): A Review of Major Developments in the Field and Recommendations for Future Research", South Asian Journal of Management, 27(1), 28-53.

Polat, M. (2009). “Örgütsel Özdeşleşmenin Öncülleri ve Ardılları Üzerine Bir Saha Çalışması”, Doktora Tezi, Uludağ Üniversitesi, Sosyal Bilimler Enstitüsü, Bursa.

Scott, M.E. (2020). "Identifying Barriers to Organizational Identification among Low-Status, Remote Healthcare Workers", Communication Studies, 71(4), 685-698.

Tajfel, H. (1978). Differentiation Between Social Groups: Studies in the Social Psychology of Intergroup Relations, Academic Press, London.

Tanyıldızı, İ. ve Demir, Ö. (2019). “Sağlık Kurumlarında Yalın Yönetim”, Fırat Üniversitesi İİBF Uluslararası İktisadi ve İdari Bilimler Dergisi, 3(1), 13-40.

Tekingündüz, S., Karabel, E., Zekioğlu, A. and Ömür Sünbül, S. (2020). "Modeling the Relationship Between Organizational Trust, Job Performance, Identity and Organizational Identification", Journal of Business ResearchTurk, 12(2), 1192-1206.

Tınaz, B. (2019). "Yalın Yönetim Sistemlerinin Hastanelerde Uygulanabilirliği Üzerine Bir Araştırma”, Yüksek Lisans Tezi, Trakya Üniversitesi, Sosyal Bilimler Enstitüsü, Edirne.

Tokgöz, E. ve Aytemiz Seymen, O. (2013). “Örgütsel Güven, Örgütsel Özdeşleşme ve Örgütsel Vatandaşlık Davranışı Arasındaki İlişki: Bir Devlet Hastanesinde Araştırma", Öneri Dergisi, 10, 39, 61-76.

Türkan, Ö.U. (2010). "Üretimde Yalın Dönüşümün Temel Performans Kriterleri”, BAÜ Fen Bil. Enst. Dergisi 12(2), 2841.

Tüzün, İ.K. (2006). “Örgütsel Güven, Örgütsel Kimlik ve Örgütsel Özdeşleşme İlişkisi, Uygulamalı Bir Çalışma”, Doktora Tezi, Gazi Üniversitesi, Sosyal Bilimler Enstitüsü, Ankara.

Tyler, T.R. and Bies, R.J. (1990). "Beyond Formal Procedures: The Interpersonal Context of Procedural Justice”, Applied Social Psychology and Organizational Settings, 77, 98.

Uğurluoğlu, Ö., Durukan Köse, S. ve Köse, T. (2015). "Sağlık Çalışanlarının Hizmetkar Liderlik Algılarının Lider-Üye Etkileşimi ve Örgütsel Güven Üzerindeki Etkisi”, Türkiye Sosyal Araştırmalar Dergisi, 19(2), 239-262.

Wee, H. M. and Wu, S. (2009). "Lean Supply Chain and its Effect on Product Cost and Quality: A Case Study on Ford Motor Company", Supply Chain Management: An International Journal, 14(5), 335-341.

Yetgin, S. ve Sur, H. (2017). "Sağlık Çalışanlarının Demografik Özelliklerine göre Yalın Yönetim Algıları Arasındaki İlişki”, 5. Medicabil Bilimsel Etkinlikleri Uluslararası Katılımlı "Yalın Hastane Kongresi”, 26-25 Mart, Bursa.

Yu, M.C., Mai, Q., Tsai, S.B. and Dai, Y. (2018). “An Empirical Study on the Organizational Trust, EmployeeOrganization Relationship and Innovative Behavior from the Integrated Perspective of Social Exchange and Organizational Sustainability", Sustainability, 10(3), 864. 